\title{
ELDERLY SATISFACTION TOWARDS THE INTEGRATED HEALTH POST (ES- IHP) QUESTIONNAIRES: VALIDATION USING RASCH MODELING
}

\author{
Sharon Gondodiputro ${ }^{1}$, Fathihah Sabila Wiwaha ${ }^{2}$ and Merry Wijaya ${ }^{1}$ \\ ${ }^{1}$ Department of Public Health, Faculty of Medicine, Universitas Padjadjaran Bandung Indonesia, \\ ${ }^{2}$ Faculty of Medicine, Universitas Padjadjaran Bandung Indonesia
}

Corresponding author: Sharon Gondodiputro

Email: sharon_gondodiputro@yahoo.com

\begin{abstract}
Integrated Health Post for the elderly (Posbindu) has been carried out to improve the health status of the elderly, but Posbindu's utilization is still unsatisfactory. Satisfaction of the elderly towards the health care provided at the Posbindu contributed to their adherence. So far there is no instrument to measure the level of elderly satisfaction. The objectives of the study were to develop and assess the validity and reliability of the elderly satisfaction towards the integrated health post questionnaire using Rasch modeling. A cross-sectional study was carried out on 202 elderly from 16 Posbindu in Bandung, Indonesia. This study was performed from August to December 2019. The questionnaire was developed from a qualitative study, consisted of 36 items that covered the satisfaction concepts of structure, process, and output. Nine analytic tests were carried out, namely, the person fit order, person reliability, Cronbach's alpha, item reliability, item fit order, separation, the Wright map analysis, rating scale, and the differential item functioning as implemented by the Winstep version 3.73 software. Overall, the questionnaire demonstrated promising results. The overall value of person reliability was 0.93 with Cronbach's alpha of 0.96 and the value of item reliability was 0.94 . However, 3 items were misfits and should be considered to be revised or removed. Further studies involving various regions in Indonesia should be carried out before this questionnaire is used in Indonesia.
\end{abstract}

Keywords: Elderly, ES-IHP, integrated health post, Rasch modeling

\section{INTRODUCTION}

Indonesia as one of the most populated countries in the world faces a change in its population structure. It is estimated that there will be an increase in the proportion of $>65$ years old population from $6.9 \%$ in 2019 to $10.3 \%$ in $2035 .{ }^{1}$ In response to the aging population, the Indonesian Ministry of Health, through decree number 25/2016, developed a National Action Plan for the welfare of the elderly. It is clearly stated that the government motivates the empowerment of the community to build community support groups/integrated health posts so that the elderly will stay healthy, independent, and productive. ${ }^{2}$ In the year 2019 , there are 59,804 integrated health posts for the elderly (Posbindu), spread in the 34 provinces in Indonesia, most of them located in the 3 provinces in Java island, namely West Java, Central Java, and East Java. ${ }^{3}$ The utilization of the Posbindu is not as expected. In many areas in Indonesia, the percentage of utilization is far less than the national target. ${ }^{4,5}$ Many studies had been carried out to identify the factors that contributed to the underutilization of the Posbindu. Most of them discovered that the main factors were the lack of the elderly's knowledge towards the health care provided at the Posbindu, minimum family support, and the role of the community volunteers/cadres. ${ }^{4,5}$
The perception of the elderly towards the health care provided at the Posbindu influences the level of satisfaction towards the quality of the health care. Low satisfaction causes the low motivation of the elderly to come to the Posbindus. ${ }^{6}$ Satisfaction makes the elderly eager to come to the Posbindu. ${ }^{7}$ The gap between patients' expectations and health care performance results in satisfaction or dissatisfaction. ${ }^{8}$ A study by Yusri et al discovered that there was a correlation between satisfaction and loyalty. ${ }^{9}$ A qualitative study conducted in Bandung West Java by Azana et. al, identified factors that contributed to the elderly's satisfaction towards the health care provided at the Posbindu. ${ }^{10}$ Those factors consisted of 32 categories divided into 6 subthemes and 3 themes. ${ }^{10}$

To motivate the elderly to come to the Posbindu, actions based on quantitative evidence need to be measured. Before measuring the elderly's satisfaction, the development and validation of a questionnaire based on the study of Azana et.al. should be carried out. So far, no questionnaire has been developed to measure the elderly's satisfaction towards the health care provided at the Posbindu. Rasch modeling as a psychometric technique, which was first developed by the Danish mathematician Georg Rasch in 1960, offers researchers to investigate the weakness, strength, and quality of an instrument, based on Item Response Theory. ${ }^{11,12}$ The objectives of the 
study were to develop and validate the elderly's satisfaction towards health care provided at the Posbindu (ES-IHP) questionnaire using Rasch modeling.

\section{METHODS}

This study was conducted in two steps, namely the development and the validation of the questionnaire. The ES-IHP questionnaire was set based on a qualitative study in Bandung City, West Java. ${ }^{10}$ The concepts consisted of 3 main themes (structure, process, and input). The structure concept consisted of 3 subthemes, namely accessibility, facilities, and human resources. The process concept consisted of behavior and communication of the cadres; behavior and communication of the health providers; and health consultation and treatment. The output concept had no subtheme. ${ }^{10}$ The researchers set up positive and negative statements based on the concepts and consisted of 36 items (18 positive and 18 negative items). Each item was scored with a Likert scale from 1 to 4 (strongly disagree, disagree, agree, strongly agree). A pre-testing study was conducted on 10 elderly as the target population and was performed twice. Each pretesting consisted of 5 elderly. The inclusion criteria were as follows: 1 ) $\geq 60$ years old; 2 )visited the Posbindu in the last one year; 3)communicate well; 4)speak and write the Indonesian language; 5)had no dementia after being tested using Mini-Mental State Examination (MMSE), values of 23 or above for those with education up to high school, and 25 or above for those who underwent higher education. ${ }^{13}$ and 6 )willing to participate in this study. The aim of the pre-testing was to obtain information from the elderly whether they understood the phrase of all items without changing the initial meaning of the corresponding statements, as well as to receive inputs for improving the statements phrase.

The validation process was carried out to 202 participants from 17 Posbindus. The Posbindu were selected using random sampling by a computer. Based on the Monte Carlo simulation, the minimum sample size required is $\geq 175$ samples to meet the goodness of fit and the statistical power as a function of the sample. The higher the number of samples, the higher the acceptance of the fit model ${ }^{14}$, but in Rasch modeling, with a confidence interval of $95-99 \%$ and item calibration stability of \pm 1 logit, the minimum sample size can be only 30-50 samples. ${ }^{15}$ A total of 10 interviewers were trained to collect the data from the Posbindu. From every Posbindu, the elderly who met the inclusion criteria were selected using consecutive sampling. This study had received ethical clearance from the Ethics Committee of Universitas Padjadjaran Bandung, Indonesia,
No.513/UN6.KEP/EC/2019. The demographic characteristics of the participants were presented in percentages. Reliability and validity testing of the questionnaire was conducted using Rasch modeling using Winsteps software version 3.73. First, the person fit measure was tested to detect participants with inappropriate response patterns compared to their true satisfaction perception. ${ }^{11,16}$ The next step was to analyze the Person reliability and Item reliability tests. The value of those tests are <0.67:low; 0.67-0.80: sufficient; 0.81-0.90: good; 0.91-0.94: very good; >0.94: excellent. ${ }^{15}$ Instrument reliability is measured by Cronbach's alpha. The value of the Cronbach's alpha: <0.5: low; 0.5-0.6: moderate; 0.6-0.7: good; 0.7-0.8: high; >0.8: very high. ${ }^{15}$ Other testing were conducted in this study were item-fit order, unidimensional testing, the Wright map analysis, rating scale, and the differential item functioning.

The item-fit order determines whether each statement works well to take measurements or not. The item fit level was analyzed from the value of the outfit mean-square (MNSQ), outfit zstandardized (ZSTD), and point-measure correlation (Pt-measure Corr). If the statement items on the three criteria are not fulfilled, the statement items are not good enough. ${ }^{15}$ Unidimensional testing shows the validity of the instrument. This testing uses principal component analysis. The validity of the instrument is if there was at least $20 \%$ of the raw variance explained by measure. Furthermore, the raw variance value unexplained by measure does not exceed $15 \% .^{15}$ The Wright map analysis (person-item map) illustrates the distribution of participants' abilities and the distribution of statement difficulty levels. ${ }^{15}$ In measuring the validity of ratings on the answer choices, the rating scale analysis was conducted. If it shows successive improvements, the options given are valid for the participant. ${ }^{15}$ The last testing was the differential item functioning (DIF) test. This test is useful to find out whether there are statements containing bias based on the participant's characteristics. A statement contains a bias if the probability value is below $5 \% .{ }^{15}$

\section{RESULTS}

On the first pre-testing study, only 4 of 5 elderly (one person could not come to the place where the pre-testing was conducted because she was sick) attended this meeting. All of them were housewives and had only elementary education. Three of them aged between $60-70$ years old and only one person aged 86 years old. Two of them had MMSE scores of 30 and the other two persons had MMSE scores of 24 and 25, respectively. One of the researchers distributed the questionnaire and asked the elderly to read it slowly. They mentioned that they did not understand the 
meaning of all of the negative items. Moreover, they suggested that the font size of the questionnaire should be bigger so that they could read them easily although they wore glasses and an item should be put on one page, not cut into two sentences and written on the next page. After the researchers revised it according to the inputs by the elderly at the first pre-testing, a second pre-testing was conducted one week later. It was carried out to another 5 elderly from the same Posbindu with a similar process as in the first pre-testing. The demographic characteristics of this group were similar to the first group. They were all housewives and had only elementary education. Four of them aged between 60-70 years old dan only one person aged 79 years old. Two of them had MMSE scores of 28 and the other three persons had MMSE scores of 24, 25, and 27, respectively. The elderly had no difficulty reading and understanding all items. Based on the pre-testing study, the final ES-IHP questionnaire consisted of 36 items without negative items, 13 items of the structure consisted of 7 items of accessibility, 3 items of facilities, and 3 items of human resources; 19 items of the process consisted of 5 items of behavior and communication of the cadres; 5 items of behavior and communication of the health providers, and 9 items of health consultation and treatment; and 4 items of output.

The first step in conducting the Rasch modeling was to perform the person fit measure. This test aimed to detect participants with inappropriate response patterns compared to their true satisfaction perception. This study revealed that there were 127 participants with inappropriate (non-eligible) and 75 participants with appropriate response patterns (eligible). Its socio-demographic characteristics were described in Table 1. Among the 75 participants, most of them were 60-69 years old, female, had low education, and had no occupation. Regarding living arrangements, they were widows/widowers who live with other members of the family. Still, some participants lived alone although the percentage was low. Most of the participants attended the Posbindu regularly and came alone to the location. The health conditions of the participants were asked if they had health conditions that had already been diagnosed by a doctor or just as symptoms. This study revealed that the health conditions varied from no disease/symptom to more than two diseases/symptoms. Hypertension, Diabetes mellitus, and Osteoarthritis were the most health conditions that occurred.

The participants who had inappropriate response patterns (non-eligible) were excluded from the validation test. The person and item reliability; item fit order; Wright map analysis, unidimensionality, rating scale and, DIF were tested. Table 2 revealed the person reliability yielded 0.93 , indicated that the participant's consistency in answering the questions was very good, except the person reliability of the output yielded 0.64 and 0.76 . The Cronbach Alpha was very high, indicating that the internal consistency was very good as well. The item reliability was 0.94 , indicating that the quality of the items was very good, especially the quality of the structure items. Moreover, the separation values were high. Unidimensionality indicated by the raw variance explained by measures yielded a percentage of more than $50 \%$, however, there was one raw unexplained variance that more than $15 \%$ was on the output items.

The item fit order statistics revealed that 3 items were misconceived by the participants (Table 3). Those were 1A7: “I am willing to pay for the medical examination at Posbindu", 1C13: "doctor presents at the Posbindu", and 2C31: "providing medicine".

The Wright map/person-item map (Figure 1) showed the person's ability ranged from 7.20 logits (person number 009) to -0.23 logits (person number 141). Person number 009 was the participant who has the highest ability to answer the items, but this person is an outlier. In contrast, participant number 141 has the lowest ability to answer the items. Furthermore, more than $50 \%$ of the participants could not answer 2 items (1C13 and 2C31). These two items were also outliers. All the participants could answer 20 items easily (from $1 \mathrm{~A} 1$ to $1 \mathrm{~A} 6 ; 1 \mathrm{~B} 8$ and IB9; $1 \mathrm{C} 11$ and $1 \mathrm{C} 12$; from $2 \mathrm{~A} 14$ to $2 \mathrm{~A} 17$; 2B20, 2B21, 2B23; 2C25; $3 \mathrm{~A} 34$ and $3 \mathrm{~A} 36)$. The item difficulty ranged from 3.49 logits (item number 2C31) to 1.75 logits (item number IA6). Item number 2C31 was an item that had the most difficult to answer and item number $1 \mathrm{~A} 6$ was the item that had the easiest to answer.

Each item of the ES-IHP questionnaire was scored with a Likert scale from 1 to 4 (strongly disagree, disagree, agree, strongly agree). The four-point Likert were adequate (Table 3) since the calibrations were properly ordered. The value of the infit and outfit MNSQ was less than 2.00 .

Differential Item Functioning (DIF) map of the eight demographic characteristics was analyzed. Figures 2 showed that gender, living arrangements, and come alone or escorted to the Posbindu had no bias. On the other hand, 5 from 8 demographic characteristics had a probability below $5 \%$. The bias was located at the accessibility items (1A4 and 1A7), facilities items (1B10), and consultation and treatment items (from 2C29 to 2C32). 
Table 1.Demographic characteristics of the study sample.

\begin{tabular}{|c|c|c|c|c|c|}
\hline \multirow{2}{*}{$\begin{array}{l}\text { Characteristics } \\
(\mathrm{n}=202)\end{array}$} & & \multicolumn{2}{|c|}{ Eligibility } & \multirow[b]{2}{*}{$\begin{array}{l}\text { Total } \\
(\mathrm{n}, \%)\end{array}$} & \multirow[b]{2}{*}{$p$-value } \\
\hline & & $\begin{array}{c}\text { Non-eligible (127) } \\
(\mathrm{n}, \%)\end{array}$ & $\begin{array}{c}\text { Eligible (75) } \\
(\mathrm{n}, \%)\end{array}$ & & \\
\hline Age (years) & $\begin{array}{l}60-69 \\
\geq 70\end{array}$ & $\begin{array}{l}80(63.5) \\
47(61.8)\end{array}$ & $\begin{array}{l}46(36.5) \\
29(38.2)\end{array}$ & $\begin{array}{l}126 \\
76\end{array}$ & $.814^{a}$ \\
\hline Gender & $\begin{array}{l}\text { Male } \\
\text { Female }\end{array}$ & $\begin{array}{c}12(60.0) \\
115(63.2)\end{array}$ & $\begin{array}{l}8(40.0) \\
67(36.8)\end{array}$ & $\begin{array}{c}20 \\
182\end{array}$ & $.779^{a}$ \\
\hline Education & $\begin{array}{l}\text { Below and Equal to } \\
\text { Elementary } \\
\text { Yunior and Senior High } \\
\text { Under and Post graduate }\end{array}$ & $\begin{array}{l}83(61.9) \\
34(59.6) \\
10(90.9)\end{array}$ & $\begin{aligned} 51 & (38.1) \\
23 & (40.4) \\
1 & (9.1)\end{aligned}$ & $\begin{array}{l}134 \\
57 \\
11\end{array}$ & $.988^{\mathrm{b}}$ \\
\hline Occupation & $\begin{array}{l}\text { No } \\
\text { Yes }\end{array}$ & $\begin{array}{l}106(62.0) \\
21(67.7)\end{array}$ & $\begin{array}{l}65(38.0) \\
10(32.3)\end{array}$ & $\begin{array}{c}171 \\
31\end{array}$ & $.346^{a}$ \\
\hline Living & Alone & $5(45.5)$ & $6(54.5)$ & 11 & \\
\hline & $\begin{array}{l}\text { With spouse } \\
\text { With spouse and other } \\
\text { members of the family }\end{array}$ & $\begin{array}{l}17(60.7) \\
31(60.8)\end{array}$ & $\begin{array}{l}11(39.3) \\
20(39.3)\end{array}$ & $\begin{array}{l}28 \\
51\end{array}$ & $.522^{\mathrm{b}}$ \\
\hline & $\begin{array}{l}\text { With other members of } \\
\text { the family } \\
\text { Others }\end{array}$ & $\begin{array}{l}73(65.8) \\
1(100.0)\end{array}$ & $\begin{array}{l}38(34.2) \\
0(0.0)\end{array}$ & $\begin{array}{c}111 \\
1\end{array}$ & \\
\hline $\begin{array}{l}\text { Attendance } \\
\text { frequency }\end{array}$ & $\begin{array}{l}\text { Irregular } \\
\text { Regular }\end{array}$ & $\begin{array}{l}42(72.4) \\
85(59.0)\end{array}$ & $\begin{array}{l}16(27.6) \\
59(41.0)\end{array}$ & $\begin{array}{l}58 \\
144\end{array}$ & $.075^{\mathrm{a}}$ \\
\hline $\begin{array}{l}\text { Alone } \\
\text { escorted }\end{array}$ & $\begin{array}{l}\text { or Alone } \\
\text { Escorted }\end{array}$ & $\begin{array}{l}119(62.6) \\
8(66.7)\end{array}$ & $\begin{array}{l}71(37.4) \\
4(33.3)\end{array}$ & $\begin{array}{l}190 \\
12\end{array}$ & $.779^{a}$ \\
\hline MMSE SCORE & $\begin{array}{l}\text { Median } \\
\text { Minimum } \\
\text { Maximum }\end{array}$ & $\begin{array}{l}28 \\
24 \\
30\end{array}$ & $\begin{array}{l}28 \\
23 \\
30\end{array}$ & & $.289^{c}$ \\
\hline $\begin{array}{l}\text { Diseases/ } \\
\text { Symptoms }\end{array}$ & $\begin{array}{l}\text { No disease/symptom } \\
\text { One disease/symptoms } \\
\text { Two diseases/symptoms } \\
\text { More than two } \\
\text { diseases/symptoms }\end{array}$ & $\begin{array}{l}50(61.0) \\
40(62.5) \\
11(64.7)\end{array}$ & $\begin{array}{l}13(33.3) \\
32(39.0) \\
24(37.5) \\
6(35.3)\end{array}$ & $\begin{array}{l}82 \\
64 \\
17\end{array}$ & $.941^{a}$ \\
\hline
\end{tabular}

Notes: ${ }^{a}$ : Chi-Square test; ${ }^{\text {b}}$ : Kolmogorov-Smirnov test; MMSE: Mini-Mental State Examination; ${ }^{c}$ : MannWhitney test

Table 2. Person and item reliability, Cronbach's alpha, separation, raw variance explained, and unexplained variance.

\begin{tabular}{|c|c|c|c|c|c|}
\hline No & Reliability and validity & Structure & Process & Output & Total ES-IHP \\
\hline \multirow[t]{6}{*}{1} & Person reliability & & & & .93 \\
\hline & Non extreme & .80 & .89 & .64 & \\
\hline & Separation & 2.96 & 4.16 & 2.12 & \\
\hline & Extreme and nonextreme & .82 & .89 & .76 & \\
\hline & Separation & 3.14 & 4.07 & 2.71 & 5.36 \\
\hline & Cronbach's alpha & .89 & .94 & .86 & .96 \\
\hline \multirow[t]{2}{*}{2} & Item reliability (nonextreme) & .97 & .94 & .94 & .94 \\
\hline & Separation & 7.35 & 5.61 & 5.76 & 5.80 \\
\hline \multirow[t]{3}{*}{3} & Validity & & & & \\
\hline & Raw variance explained by measures & $55.9 \%$ & $54.0 \%$ & $59.4 \%$ & $52.1 \%$ \\
\hline & Raw unexplained variance (total) & None & None & $\begin{array}{c}\text { One Found } \\
(16.7 \%)\end{array}$ & None \\
\hline
\end{tabular}

Note: ES-IHP: Elderly Satisfaction-Integrated Health Post Questionnaire 
Table 3. Item Fit Order $(n=75)$

\begin{tabular}{|c|c|c|c|c|c|c|c|c|c|c|c|c|c|}
\hline \multirow{2}{*}{ Number } & \multirow{2}{*}{ Items } & & \multirow{2}{*}{ Total Score } & \multirow{2}{*}{ Measure } & \multirow{2}{*}{ Model S.E. } & \multicolumn{2}{|l|}{ INFIT } & \multicolumn{2}{|c|}{ OUTFIT } & \multicolumn{2}{|c|}{ PT-MEASURE } & \multicolumn{2}{|c|}{ ЕХАСТ МАТСН } \\
\hline & & & & & & MNSQ & ZSTD & MNSQ & ZSTD & CORR. & EXP. & OBS\% & EXP\% \\
\hline & Structure & & & & & & & & & & & & \\
\hline $1 \mathrm{~A} 1$ & Accessibility & $\begin{array}{l}\text { The location of the } \\
\text { Posbindu is near }\end{array}$ & 266 & -.73 & .27 & .96 & -.1 & 1.09 & .4 & J.59 & .63 & 76.0 & 76.3 \\
\hline $1 \mathrm{~A} 2$ & & Posbindu is easy to reach & 269 & -.95 & .27 & .84 & -.8 & .78 & -.5 & P.62 & .61 & 80.0 & 76.2 \\
\hline $1 \mathrm{~A} 3$ & & $\begin{array}{l}\text { Services in Posbindu are } \\
\text { carried out once a month }\end{array}$ & 272 & -1.18 & .28 & .61 & -2.3 & .64 & -.8 & 1.70 & .59 & 85.3 & 77.0 \\
\hline IA4 & & $\begin{array}{l}\text { Posbindu's opening days } \\
\text { are appropriate }\end{array}$ & 265 & -.66 & .26 & .80 & -1.0 & .97 & .0 & K.65 & .63 & 77.3 & 76.3 \\
\hline IA5 & & $\begin{array}{l}\text { Posbindu which is done in } \\
\text { the morning according to } \\
\text { my wishes }\end{array}$ & 271 & -1.10 & .28 & .81 & -1.0 & .90 & -.1 & N.65 & .60 & 76.0 & 76.8 \\
\hline IA6 & & $\begin{array}{l}\text { The medical examination } \\
\text { at Posbindu is free of } \\
\text { charge }\end{array}$ & 279 & -1.75 & .30 & .72 & -1.6 & .49 & -1.0 & $\mathrm{~m} .63$ & .53 & 82.7 & 78.9 \\
\hline IA7 & & $\begin{array}{l}\text { I am willing to pay for the } \\
\text { medical examination at } \\
\text { Posbindu }\end{array}$ & 222 & 1.59 & .20 & 1.96 & 4.9 & 2.43 & 6.5 & B. 20 & .70 & 38.7 & 60.3 \\
\hline IB8 & Facilities & The room is clean; & 260 & -.33 & .26 & .54 & -2.7 & .53 & -1.9 & f.77 & .65 & 88.0 & 75.8 \\
\hline IB9 & & The room is comfortable & 263 & -.53 & .26 & .55 & -2.7 & .74 & -.8 & 0.75 & .64 & 90.7 & 76.1 \\
\hline IB10 & & $\begin{array}{l}\text { Medical equipment } \\
\text { provided }\end{array}$ & 251 & .22 & .24 & .74 & -1.4 & .74 & -1.1 & q.74 & .67 & 81.3 & 72.9 \\
\hline IC11 & Human Resources & $\begin{array}{l}\text { Cadres of the Posbindu are } \\
\text { appropriate and adequate }\end{array}$ & 262 & -.46 & .26 & .52 & -2.9 & .46 & -2.2 & e.78 & .64 & 89.3 & 76.1 \\
\hline IC12 & & $\begin{array}{l}\text { Midwives/nurses present } \\
\text { at the Posbindu } \\
\text { The doctor presents at the }\end{array}$ & 262 & -.46 & .26 & .58 & -2.4 & .59 & -1.5 & i. 73 & .64 & 86.7 & 76.1 \\
\hline IC13 & & Posbindu & 187 & 2.90 & .19 & 2.07 & 5.5 & 2.21 & 5.8 & C. 35 & .74 & 34.7 & 58.7 \\
\hline & Process & & & & & & & & & & & & \\
\hline $2 \mathrm{~A} 14$ & $\begin{array}{l}\text { Behaviour and } \\
\text { communication of the } \\
\text { cadres }\end{array}$ & Cadres arrive on time & 260 & -.33 & .26 & .59 & -2.4 & .52 & -2.0 & h.78 & .65 & 85.3 & 75.8 \\
\hline $2 \mathrm{~A} 15$ & & Cadres are patient & 269 & -.95 & .27 & .40 & -4.0 & .30 & -2.5 & c. 81 & .61 & 90.7 & 76.2 \\
\hline $2 A 16$ & & Cadres are friendly & 271 & -1.10 & .28 & .42 & -3.9 & .31 & -2.3 & d.79 & .60 & 94.7 & 76.8 \\
\hline $2 \mathrm{~A} 17$ & & $\begin{array}{l}\text { Cadres are } \\
\text { responsive/helpful } \\
\text { Understood the }\end{array}$ & 271 & -1.10 & .28 & .57 & -2.6 & .43 & -1.7 & g.73 & .60 & 89.3 & 76.8 \\
\hline $2 \mathrm{~A} 18$ & & $\begin{array}{l}\text { explanation given by the } \\
\text { cadres }\end{array}$ & 256 & -.07 & .25 & .73 & -1.4 & .58 & -1.8 & n.79 & .66 & 84.0 & 74.9 \\
\hline
\end{tabular}




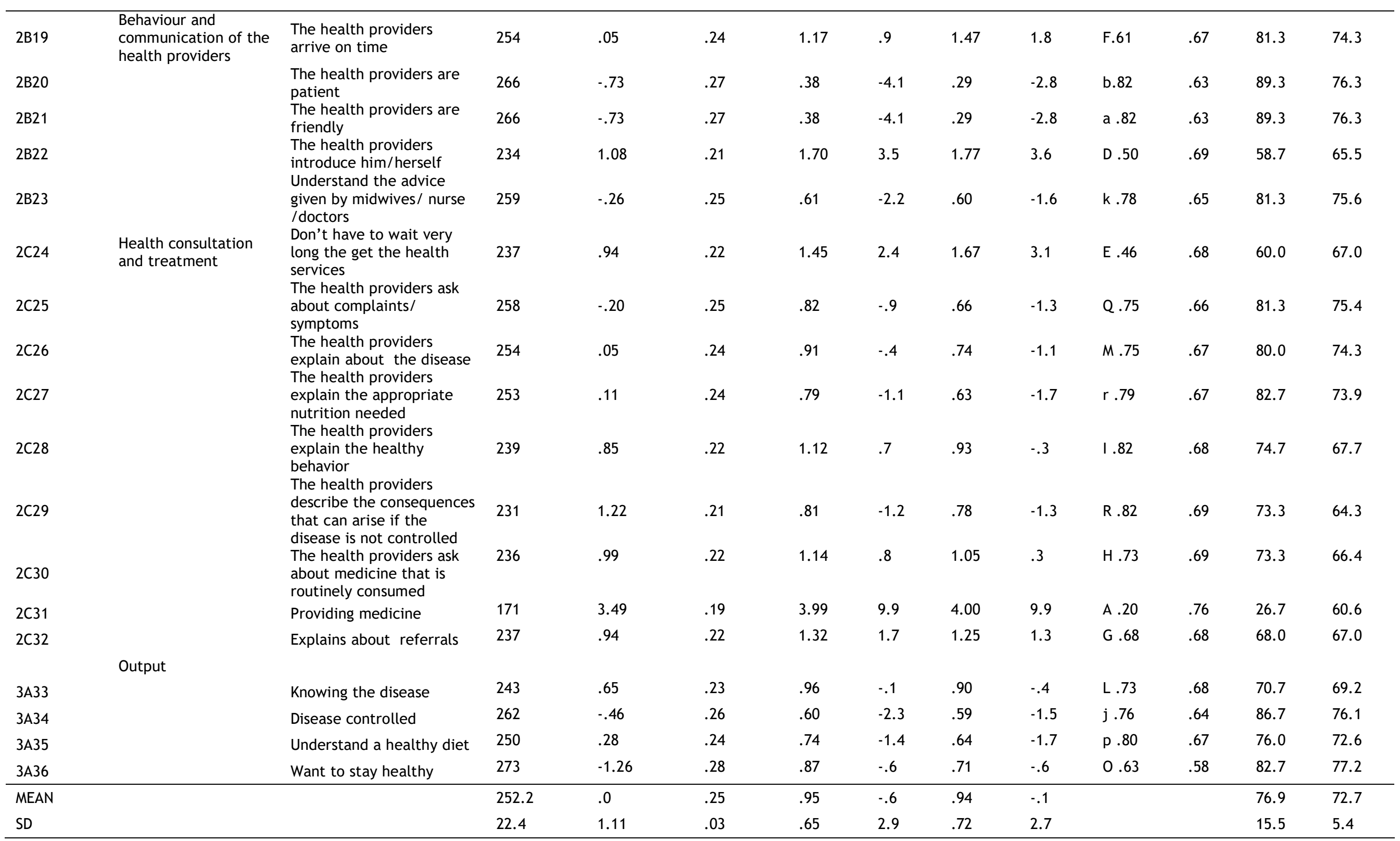

Notes:S.E: Standard Error; MNSQ: Mean Square; ZSTD: Z-standardized; PT-Measure: Point-Measure; CORR: Correlation; EXP: Expected; OBS: Observed. 


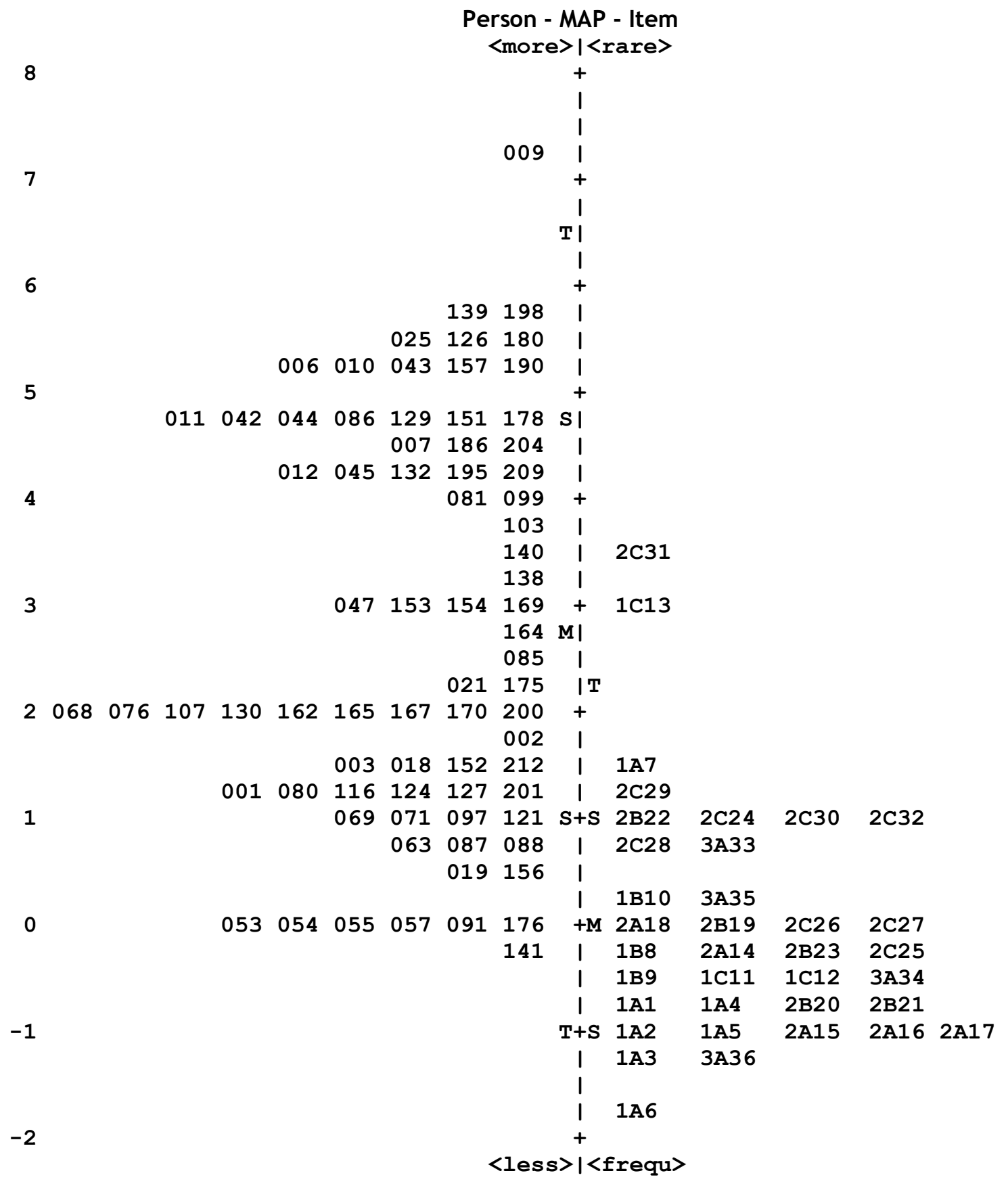

Figure 1. Wright Map Analysis

Table 3. Rating Scale of the ES-IHPQ $(n=75)$

\begin{tabular}{ccccccccc}
\multirow{2}{*}{ SCORE } & \multicolumn{2}{c}{ OBSERVED } & OBSVD & SAMPLE & INFIT & OUTFIT & ANDRICH & CATEGORY \\
\cline { 2 - 4 } & COUNT & $\%$ & AVRGE & EXPECT & MNSQ & MNSQ & THRESHOLD & MEASURE \\
\hline 1 & 52 & 2 & -1.00 & -1.58 & 1.49 & 1.58 & NONE & $(-3.40)$ \\
2 & 217 & 8 & .56 & .12 & 1.38 & 1.53 & -2.15 & -1.44 \\
3 & 1131 & 42 & 1.56 & 1.81 & .93 & .67 & -.71 & 1.11 \\
4 & 1300 & 48 & 4.41 & 4.29 & .90 & .86 & 2.86 & $(3.98)$
\end{tabular}

Notes: OBSVD AVRGE: Observed Average; MNSQ: Mean Square 

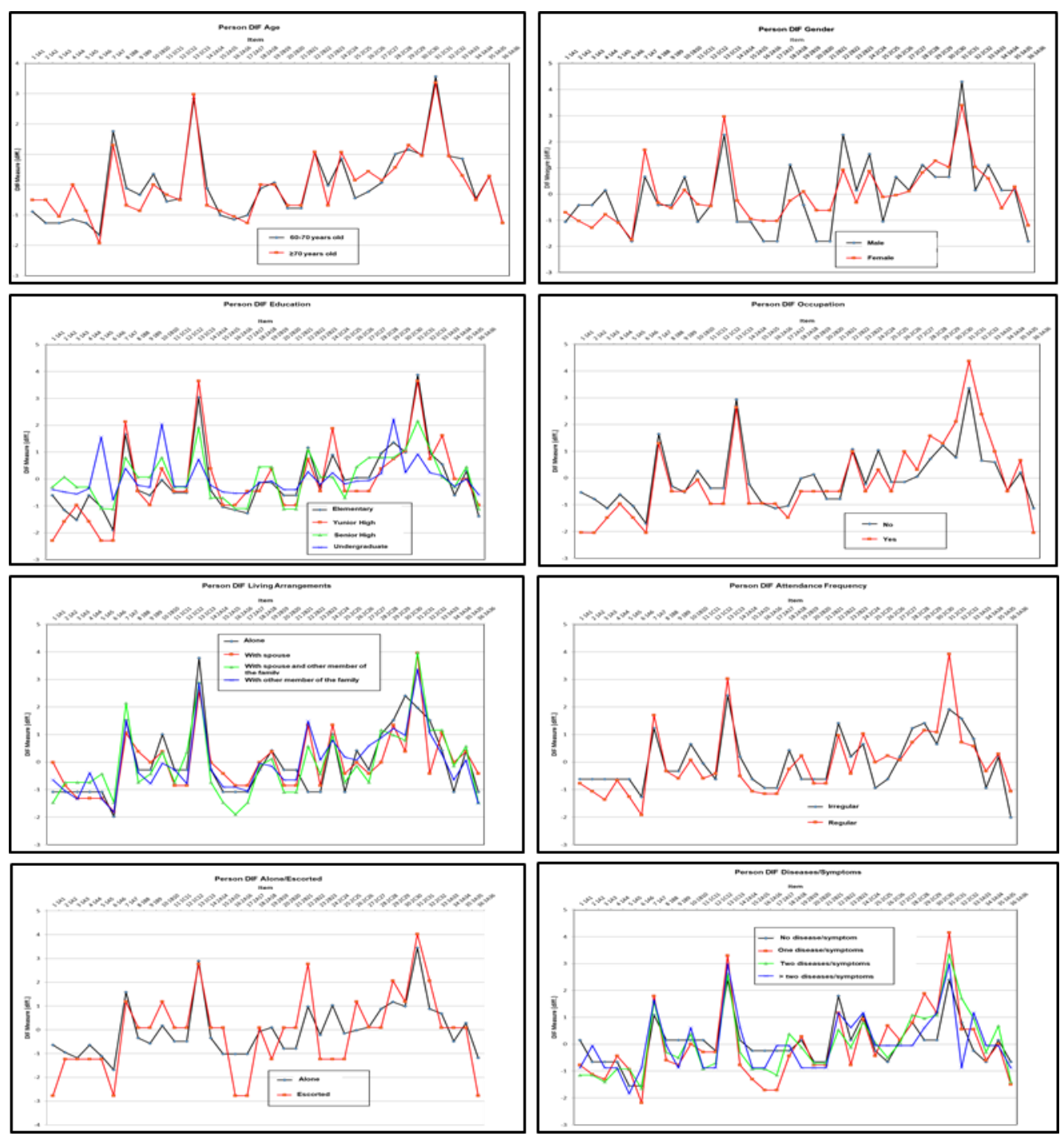

Figure 2. Differential Item Functioning (DIF) Map according to age, gender, education, occupation, living arrangements, attendance frequency, alone/escorted, and diseases/symptoms

\section{DISCUSSION}

The ES-IHP questionnaire is a new questionnaire, developed to measure the satisfaction level of the elderly towards the health care provided by the Posbindu. The result can be used as inputs for improving the quality of Posbindu. A range of statistical analyses to test the reliability and validity of a questionnaire are used in many research ${ }^{17}$, one of them is Rasch modeling. The Rasch modeling converts the nonlinear raw data to a linear scale. ${ }^{16}$ Moreover, Rasch modeling allows detecting the misconception response of the participants (person fit order), items that misfits (item fit order), person reliability, item reliability, validity, and difficult or easy items to be answered by the participants (Wright-map analysis). ${ }^{16}$ Rasch modeling can evaluate the proper rating scale use in a questionnaire and allow the detection of bias responses according to various participants' characteristics. ${ }^{16}$
This study revealed that there were 127 of 202 participants who had inappropriate responses according to the person fit order test. Boone and Noltemeyer detected several causes of the inappropriate responses, among others, the misfitting participants differ in some way from the target population of interest, there is a pattern of selecting random answers or guessing, the item misunderstood, and the item measures the trait in a different way than originally intended. ${ }^{11}$ In this study, the Chi-square test or Kolmogorov-Smirnov test was carried out to detect the cause of the inappropriate responses based on the characteristics of the participants. The test revealed that there was no difference in the characteristics variables between the misfit and fit groups, so it is not yet known the cause of this inappropriate answer.

After the misfit participants were excluded, other statistical tests in Rasch modeling were conducted. The item fit order test showed that there were 3 items that misfits. Those were 1A7: "I am willing to pay for the medical examination 
at Posbindu", 1C13: "doctor presents at the Posbindu, and 2C31: "providing medicine". The Posbindu is established by the local community themselves and operated by cadres/community volunteers from the same community, free of charge. ${ }^{18}$ The purpose of Posbindu is to provide promotive and preventive health services according to the needs of the elderly ${ }^{19}$ and is not allowed to provide medicine. If the elderly need medicine, the health providers refer them to the Public Health Center (Puskesmas). The health provider present is usually a nurse or midwife, rarely a doctor. Therefore, these three items become a misfit. This may be the reasons for an inappropriate response.

Various reliability testing was conducted in this study such as person reliability, item reliability, separation, and Cronbach's alpha. ${ }^{20}$ Those tests revealed a high result. These findings describe that there was consistency in the answers of the participants and each item had adequate quality, except the three items that have been mentioned before. This internal consistency showed that the items in each category measured the same concept and also showed the interrelation of the statements. ${ }^{21}$ The validity of the ES-IHP questionnaire measured by the unidimensional test, showed a promising result. The raw variance values explained by measure revealed more than $20 \%$ and only 1 of the raw unexplained variance values more than $15 \%$ in the output category. If unidimensionality is not achieved, there is no point to compute a total measure and "compare" respondents or items ${ }^{20}$ The result of the reliability and validity test proves that the ES-IHP questionnaire consistently measures the same concept, show the interrelation of the statements, and measure what should be measured. ${ }^{21}$

Person-item or Wright Map analysis, which is named in honor of the University of Chicago's Benjamin Wright, describes both person measures and item measures on the same linear scale. ${ }^{16}$ It provides information on the hierarchy of the ability level of the participants and item difficulties. ${ }^{16,22}$ The higher the logit value of the person measure, the higher the person's ability, and the lower the logit value, the lower the person's ability. On the other hand, the higher the logit value of the item measure, the difficult the item to be answered, and the lower the logit value the easy the item to be answered. ${ }^{16,22}$ The Wright Map analysis provides also the person and items located outside the map (outliers). Outliers are observations that are different from the majority of other cases in a sample. ${ }^{23}$ This study revealed item number 1C13: "doctor presents at the Posbindu" and 2C31: "providing medicine" were outliers.

In developing the items in the ES-IHP questionnaire, the researchers had already made 18 negative-phrased statements of 36 statements. The objectives to set up negativephrased statements are to keep respondents attentive to not repeat choosing the same answer as the previous choice for all the remaining items. ${ }^{20}$ The first pre-testing study discovered that all of the respondents did not understand the meaning of all of the negativephrased items, therefore the researchers revised the negative-phrased items to positive-phrased items. Even though there were no negativephrased items, the item fit order test only discovered 3 items that were not fit in the model. Moreover, the result of the Rating Scale test yielded encouraging results. Although the Likert scale measures increase monotonically from the lowest rating point to the highest rating point, the Infit and Outfit mean squares are less than 2, but it is found that not all the thresholds were at least 1,4 logits greater than the last. ${ }^{11,24}$ The participants had no difficulties discriminating among categories from strongly disagree, disagree, agree, to strongly agree.

Differential Item Functioning (DIF) is a technique to identify bias in item response according to some characteristics of the participants. ${ }^{20}$ DIF simply means that an item measures a trait in a different way for the two or more compared groups. ${ }^{20}$ This study discovered that some items had bias according to the characteristics of the respondents. The potential biases can be caused by variations of the participants' characteristics or the use of the language in the questionnaire. An item that produced DIF is not necessarily unfair to various subgroups of respondents, because sometimes the language or the vocabulary used in the questionnaire is more easily understood by one group as opposed to another. ${ }^{20}$

Rasch modeling has been used widely to test the validity and reliability of a questionnaire. The application of the Rasch modeling allows researchers to conduct a detailed analysis of the items and participants; to use parametric statistics since the categorical data are transformed in numerical data (logits); and to explain the meaning of the differences among groups of participants using items. ${ }^{11,25}$

The Rasch analysis of the ES-IHP questionnaire seems to be satisfactory, but there are still various limitations. In this study, the sample came from one district and may not represent the Indonesian general population. Studies in various districts should be carried out in the future.

\section{CONCLUSION}

In conclusion, the ES-IHP questionnaire demonstrates good results using the Rasch modeling, however, there are three items (IA7, IC13, and 2C31) that should be considered to be excluded from the questionnaire. 


\section{Conflict of interest}

The authors affirm no conflict of interest in this study.

\section{Acknowledgements}

We would like to thank Dr. Deni S. Sunjaya, dr., DESS who permitted the researchers to use Winstep version 3.73. We also would like to thank the participants from Bandung who were eagerly participated in this study.

\section{REFERENCES}

1. United Nations Department of Economic and Social Affairs Population Division. World Population Ageing 2019, Highlights. New York: United Nations; 2019.

2. Indonesian Ministry of Health. Decree Number 25/2016 about The National Action Plan for the Welfare of the Elderly. 2019.

3. Indonesian Ministry of Health. Indonesia Health Profile, 2019. Jakarta: Ministry of Health; 2020.

4. Melita, Nadjib M. Faktor-faktor yang berhubungan dengan kunjungan lansia ke Posbindu lansia di wilayah kerja puskesmas Kelurahan Bintara Kota Bekasi tahun 2017. J Kebijak Kesehat Indones. 2018;07(04):15867.

5. Purnama S, Sudirman, Yusuf $\mathrm{H}$. Faktor yang berhubungan dengan pemanfaatan posyandu lansia Desa Tikopo Kecamatan Bokat Kabupaten Buol. J Kolaboratif Sains. 2018;1(1):700-10.

6. Saraisang $C M$, Kumaat $L T$, Katuuk ME. Hubungan pelayanan posyandu lansia dengan tingkat kepuasan lansia di wilayah kerja Puskesmas Ranomuut Kecamatan Paal II Kota Manado. e-Journal Keperawatan. 2018;6(1):1-8.

7. Tamsuri A, Arismadani Y. Gambaran tingkat kepuasan lansia terhadap pelayanan posyandu lansia. AKP. 2014;5(2):39-47.

8. Astuti HJ, Nagase K. Patient loyalty to health care organizations: Strengthening and weakening (satisfaction and provider switching). J Med Mark. 2014;14(4):191-200.

9. Yusri CR, Hidayat $M$, Djuhaeni $H$. Role of satisfaction with health care services in increasing patient loyalty: an ambulatory setting. Althea Med J. 2017;4(3):329-34.

10. Azana DW, Gondodiputro S, Didah D. Elderly's expectations of services in integrated health post (Posbindu): A qualitative study. Maj Kedokt Bandung. 2019;51(4):213-20.

11. Boone WJ, Noltemeyer A. Rasch analysis: A primer for school psychology researchers and practitioners. Cogent Educ. 2017;4(1).

12. Foster GC, Min H, Zickar MJ. Review of item response theory practices in organizational research: Lessons learned and paths forward. Organ Res Methods. 2017;20(3):465-86.

13. Woodford HJ, George J. Cognitive assessment in the elderly: A review of clinical methods. Qjm. 2007; 100(8):469-84.

14. Colin R M, Caroline J Hollins $M$. Minimum sample size requirements for a validation study of the Birth Satisfaction Scale-Revised (BSS-R). J Nurs Pract. 2017;1(1):25-30.

15. Sumintono B, Widhiarso W. Aplikasi model Rasch untuk penelitian ilmuilmu sosial. Cimahi: Trim Komunikata Publishing House; 2014. 112 p.

16. Boone WJ. Rasch analysis for instrument development: why, when, and how? CBE Life Sci Educ. 2016;15(4).

17. Taherdoost H. Validity and reliability of the research instrument; how to test the validation of a questionnaire/survey in a research. Int J Acad Res Manag. 2016;5(3):2836.

18. Pratono A, Maharani A. Long-term care in Indonesia: The role of integrated service post for elderly. J Aging Health. 2018;0(0):1-19.

19. Indonesian Ministry of Health. Pedoman pengelolaan kegiatan kesehatan di kelompok lanjut usia. Jakarta: Ministry of Health; 2010.

20. Boone WJ, Yale MS, Staver JR. Rasch analysis in the human sciences. Dordrecht: Springer; 2014.

21. Tavakol M, Dennick R. Making sense of Cronbach's alpha. Int J Med Educ. 2011;2:53-5. 
22. Wright BD. Solving measurement problems with the Rasch Model. J Educ Meas. 1977;14(2):97-116.

23. Mahapatra APK, Nanda A, Mohapatra BB, Padhy AK, Padhy I. Concept of outlier study: The management of outlier handling with significance in inclusive education setting. Asian Res J Math. 2020;16(10):7-25.

24. Van Zile-Tamsen C. Using Rasch analysis to inform rating scale development. Res High Educ. 2017;58:922-33.

25. Mohamad MM, Sulaiman NL, Sern LC, Salleh KM. Measuring the validity and reliability of research instruments. Procedia - Soc Behav Sci. 2015;204:164-71. 